\title{
Novel deleterious mutation in MYO7A, TH and EVC2 in two Pakistani brothers with familial deafness
}

\author{
Bibi Sabiha ${ }^{1}$, Johar Ali², \\ Yasar Mehmood Yousafzai ${ }^{3}$, Syed Adnan Haider ${ }^{4}$
}

\begin{abstract}
Objective: In Pakistan, 74\% of consanguineous marriages are among the first cousins. Continuity of consanguineous marriages over generations increases the risk of recessive diseases such as deafness. The objective of this study was to investigate genetic origin of Pakistani deaf brothers with parents of consanguineous marriage.

Methods: DNA was extracted from the blood through Qiagen kit. Paired-end sequencing library was prepared according to protocol of Illumina's TruSight Rapid Capture kit and TruSight Inherited Disease Panel. Library was normalized and used for Next Generation Sequencing through MiSeq. NGS data were analyzed using various bioinformatics tools.

Results: Both brothers were found to have novel deleterious mutation in MYO7A (c.2476G>A) while the younger brother had additional novel deleterious mutation in $T H$ (c.43C>T) and EVC2 (c.2614C>T) genes.

Conclusion: It is concluded that in addition to novel mutations in MYO7A, TH and EVC2, the CDH23 and GJB2 can also be responsible for deafness in the family with consanguineous marriages.
\end{abstract}

KEYWORDS: Deafness, EVC2, MYO7A, Next Generation Sequencing, TH.

How to cite this:

doi: https://doi.org/10.12669/pjms.35.1.98

Sabiha B, Ali J, Yousafzai YM, Haider SA. Novel deleterious mutation in MYO7A, TH and EVC2 in two Pakistani brothers with familial deafness. Pak J Med Sci. 2019;35(1):17-22. doi: https://doi.org/10.12669/pjms.35.1.98

This is an Open Access article distributed under the terms of the Creative Commons Attribution License (http://creativecommons.org/licenses/by/3.0), which permits unrestricted use, distribution, and reproduction in any medium, provided the original work is properly cited.

\footnotetext{
1. Bibi Sabiha,

2. Johar Ali,

3. Yasar Mehmood Yousafzai,

Institute of Basic Medical Sciences,

Khyber Medical University,

Peshawar, Pakistan.

4. Syed Adnan Haider,

1,2,4: Center for Genomic Sciences,

Rehman Medical College,

Phase-V, Hayatabad,

Peshawar, KP, Pakistan.

Correspondence:

Bibi Sabiha,

Center for Genomic Sciences,

Rehman Medical College,

Phase-V, Hayatabad,

Peshawar, KP, Pakistan.

Email: bibi.sabiha@rmi.edu.pk

* Received for Publication:

May 31, 2018

* $\quad 1^{\text {st }}$ Revision Received:

June 1, 2018

* $\quad 2^{\text {nd }}$ Revision Received:

November 12, 2018

* Final Revision Accepted:
}

\section{INTRODUCTION}

The word consanguinity describe unions between couples who share at least one common ancestor. ${ }^{1}$ Consanguineous marriages are preferred in South Asia. According to the Pakistan Demographic and Health Survey (2012-2013), approximately 65\% of marriages were consanguineous, out of which $74 \%$ were among first cousins. ${ }^{2}$ The recessive disorders show the highest association with consanguinity $(78.8 \%) .{ }^{3}$ Consanguinity is a recognized high-risk factor among the etiological factors for deafness. ${ }^{4}$ Although environmental factors are involved in deafness, the genetic defects have been reported to play a major role contributing to estimated $60 \%$ of hearing loss (HL). ${ }^{5}$ The spectrum of genetic mutations involved in deafness vary amongst different populations. ${ }^{6}$ Most highly studied gene in different populations is GJB2 (OMIM: 121011) encoding gap junction protein, beta-2 
and account for $50 \%$ of non-syndromic hearing loss (NSHL) throughout the world. ${ }^{7}$ Connexins are trans-membrane proteins that have a role in communication and transferring of ions and small signaling molecules between cells. ${ }^{8}$ This locus is already been reported in Pakistani and Mediterranean families supporting that GJB2 is the main gene for inherited sensorineural deafness. ${ }^{9}$ More than 90 variants in GJB2 have been reported and meta-analysis in different ethnic group confirmed a strong association of GJB2 mutation with $\mathrm{HL}$ in different population. ${ }^{10}$

In addition to GJB2, $>80$ mutations in MYO7A (OMIM: 276903) encoding myosin VIIA have also been linked with syndromic and NSHL. ${ }^{11}$ MYO7A co-ordinates between the transduction channel and stereocilia membrane and interact with hair cells by associating with cadherin molecules. Lack of function within the cochlear hair cells leads to development of deafness. ${ }^{12}$ Similarly, $\mathrm{CDH} 23$, (OMIM: 605516) gene encoding Cadherin-23 showed mutation in both NSHL (DFNB12) and Usher syndrome type ID (USH1D). ${ }^{13}$ CDH23 contain 69 exons and codes 3,354-aminoacid protein comprising 27 cadherin extracellular (EC) repeats, a transmembrane domain and a unique cytoplasmic domain. Function of $\mathrm{CDH} 23$ has not yet been defined but it is hypothesized to be involved in cell-cell adhesion because of its similarity in structure with Epithelial Cadherin (E-Cadherin) which has role in homophilic cellcell adhesion. ${ }^{14}$ Additionally, genetic variations in TH (OMIM: 191290) and EVC2 (OMIM: 607261) encoding Tyrosine Hydroxylase and EvC Ciliary Complex Subunit 2 respectively, have also been reported in deafness.

It is hypothesized that the spectrum of genetic mutations in Pakistani population with hereditary hearing loss might be different from elsewhere. This study set out to use advanced Next Generation Sequencing (NGS), MiSeq (Illumina, San Diego, US), to determine the genetic variation of GJB2, MYO7A, CDH23, TH and EVC2 in two Pakistani deaf brothers.

\section{METHODS}

Subject description and sample collection: The study was approved by the Institutional Review Board (IRB) at Rehman Medical Institute (RMI) Peshawar, Pakistan (Ethics approval no. DMR/RS/ JA/CGS/01).

Two deaf brothers (15 and 23years old), were recruited for targeted gene sequencing after taking

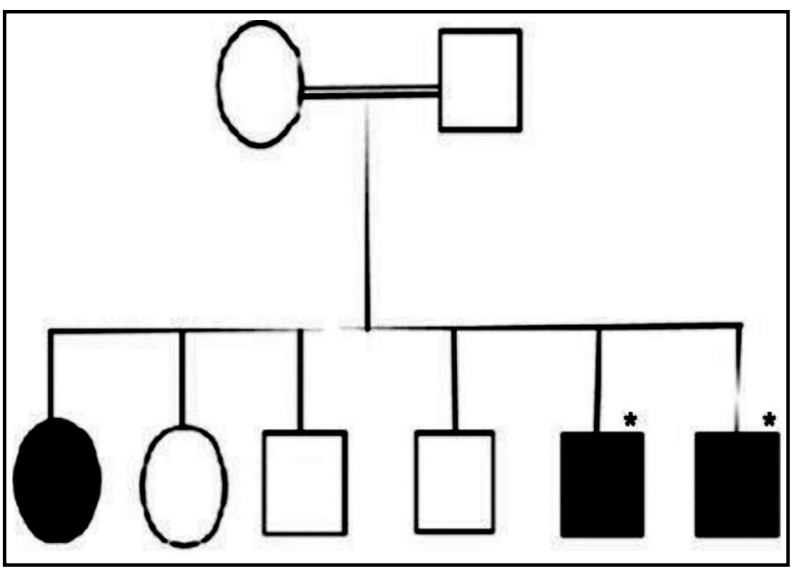

Fig.1: Pedigree of the affected family. Circles represent female and squares male family members. Affected individuals are denoted by shaded squares and circles. Asterisk shows the subjects underwent molecular study.

informed consent. Patient history revealed that their parents, two brothers and one sister were normal, however, one sister was deaf (Fig.1). Their parents were also second cousins and were not available for genetic study. The patients were clinically assessed in the ENT department of the RMI by a qualified ENT specialist. Examination of the ENT revealed no anatomical abnormality or signs of infection or inflammation. Pure Tone Audiometry (PTA) was performed which confirmed bilaterally sensorineural hearing defect with no difference between air and bone conduction. Subsequently the patients were labelled as 'deaf'. Two ml peripheral whole blood sample was drawn from the subjects in EDTA tubes by phlebotomist using aseptic techniques.

DNA extraction, quantification and normalization: DNA was extracted from blood samples through Qiagen DNA mini kit (Qiagen, Cat. no. 69504). It was then quantified with help of dsDNA high sensitivity kit (Qubit, Cat. no. Q32851) using Qubit fluorometer and normalized to $5 \mathrm{ng} / \mu \mathrm{L}$.

Library preparation: According to Illumina's TruSight Rapid Capture kit (Cat. no. FC-140-1103) and TruSight Inherited Disease Panel (Cat. no. FC-121-0205) protocol, libraries for paired-end sequencing were prepared from extracted DNA. TruSight Inherited Disease Panel covers 552 genes associated with severe, recessive pediatric onset disease.

Data analysis: FASTQ files were separated by CASAVA and trimmomatic tool was used to filter the low quality reads $(Q>30)$. The filtered reads were aligned to the reference genome (hg19/ 
Table-I: Variation detected in GJB2, MYO7A and CDH23 genes in both brothers.

\begin{tabular}{|c|c|c|c|c|c|c|c|c|c|c|}
\hline Genes & Chr:Pos & Ref/Alt & Identifier & $H G V S c$ & $\begin{array}{l}\text { Conse- } \\
\text { quences }\end{array}$ & $\begin{array}{l}\text { Elder } \\
\text { brother }\end{array}$ & $\begin{array}{l}\text { Coverage } \\
\text { Depth }\end{array}$ & $\begin{array}{c}\text { Youn- } \\
\text { ger } \\
\text { brother }\end{array}$ & $\begin{array}{c}\text { Allele } \\
\text { Fre- } \\
\text { quency } \\
(\text { ExAC) }\end{array}$ & Coverage Depth \\
\hline GJB2 & 13:20761888 & $\begin{array}{c}\mathrm{C}>\mathrm{T} / \\
\mathrm{T}\end{array}$ & rs7623 & c. ${ }^{*} 1152 \mathrm{G}>\mathrm{A}$ & $\begin{array}{c}\text { 3_prime_- } \\
\text { UTR_var- } \\
\text { iant }\end{array}$ & Homo $^{1}$ & $\begin{array}{c}\text { T: } 46 \\
(100 \%, \\
30+, 16-)\end{array}$ & Homo $^{1}$ & N/A & $\begin{array}{c}\text { G: } 1(1 \%, 1+, 0-) \mathrm{T}: 106 \\
(99 \%, 62+, 44-)\end{array}$ \\
\hline GJB2 & 13:20761973 & $\begin{array}{c}\mathrm{C}>\mathrm{A} / \\
\mathrm{A}\end{array}$ & rs9237 & c. ${ }^{*} 1067 \mathrm{G}>\mathrm{T}$ & $\begin{array}{c}\text { 3_prime_- } \\
\text { UTR_var- } \\
\text { iant }\end{array}$ & Homo $^{1}$ & $\begin{array}{c}\text { A: } 44 \\
(100 \%, \\
25+, 19-)\end{array}$ & Homo $^{1}$ & N/A & A: $74(100 \%, 40+, 34-)$ \\
\hline GJB2 & 13:20761763 & $\begin{array}{c}\mathrm{A}>\mathrm{G} / \\
\mathrm{G}\end{array}$ & rs7988691 & c. ${ }^{*} 1277 \mathrm{~T}>\mathrm{C}$ & $\begin{array}{c}\text { 3_prime_- } \\
\text { UTR_var- } \\
\text { iant }\end{array}$ & $\begin{array}{l}\text { No } \\
\text { change }\end{array}$ & - & Homo $^{1}$ & N/A & G: $22(100 \%, 9+, 13-)$ \\
\hline GJB2 & 13:20762956 & $\begin{array}{c}\mathrm{A}>\mathrm{G} / \\
\mathrm{G}\end{array}$ & rs3751385 & c. ${ }^{*} 84 \mathrm{~T}>\mathrm{C}$ & $\begin{array}{c}\text { 3_prime_- } \\
\text { UTR_var- } \\
\text { iant }\end{array}$ & $\begin{array}{l}\text { No } \\
\text { change }\end{array}$ & - & Homo $^{1}$ & $\mathrm{~N} / \mathrm{A}$ & G:30 (100\%, 15+, 15-) \\
\hline $\begin{array}{l}\text { MY- } \\
\text { O7A }\end{array}$ & $11: 76853783$ & $\begin{array}{c}\mathrm{T}>\mathrm{C} / \\
\mathrm{C}\end{array}$ & rs1052030 & c. $47 \mathrm{~T}>\mathrm{C}$ & $\begin{array}{c}\text { missense } \\
\text { variant }\end{array}$ & Homo $^{1}$ & $\begin{array}{c}\text { C: } 4 \\
(100 \%, 2+, \\
2-)\end{array}$ & Homo $^{1}$ & 0.43 & C: $10(100 \%, 6+, 4-)$ \\
\hline $\begin{array}{l}\text { MY- } \\
\text { O7A }\end{array}$ & $11: 76919478$ & $\begin{array}{c}\mathrm{C}>\mathrm{A} / \\
\mathrm{A}\end{array}$ & rs948962 & c. $5860 \mathrm{C}>\mathrm{A}$ & $\begin{array}{c}\text { missense } \\
\text { variant }\end{array}$ & Homo $^{1}$ & $\begin{array}{c}\text { A: } 25 \\
(100 \%, \\
12+, 013-)\end{array}$ & Homo $^{1}$ & 0.47 & A: $77(100 \%, 39+, 38-)$ \\
\hline $\begin{array}{l}\text { MY- } \\
\text { O7A }\end{array}$ & $11: 76912636$ & $\begin{array}{c}\mathrm{A}>\mathrm{T} / \\
\mathrm{T}\end{array}$ & rs2276288 & c. $4996 \mathrm{~A}>\mathrm{T}$ & $\begin{array}{c}\text { missense } \\
\text { variant }\end{array}$ & Homo $^{1}$ & $\begin{array}{c}\text { T: } 10 \\
(100 \%, 4+, \\
6-)\end{array}$ & Homo $^{1}$ & 0.54 & T: $37(100 \%, 16+, 21-)$ \\
\hline $\mathrm{CDH} 23$ & 10:73501556 & $\begin{array}{c}\mathrm{G}>\mathrm{A} / \\
\mathrm{A}\end{array}$ & rs1227051 & c. $4723 \mathrm{G}>\mathrm{A}$ & $\begin{array}{c}\text { missense } \\
\text { variant }\end{array}$ & Homo $^{1}$ & $\begin{array}{c}\text { A: } 22 \\
(100 \%, \\
11+, 11-)\end{array}$ & Homo $^{1}$ & 0.77 & $\begin{array}{l}\text { A:48 }(96 \%, 25+, 23-) \\
\text { C:2 }(4 \%, 0+, 2-)\end{array}$ \\
\hline $\mathrm{CDH} 23$ & 10:73270906 & $\begin{array}{c}\mathrm{T}>\mathrm{T} / \\
\mathrm{C}\end{array}$ & rs3802720 & c. $366 \mathrm{~T}>\mathrm{C}$ & $\begin{array}{l}\text { synony- } \\
\text { mous_- } \\
\text { variant }\end{array}$ & $\mathrm{Het}^{2}$ & $\begin{array}{c}\text { C: } 9(36 \%, \\
4+, 5-) \\
\text { T: } 16(64 \%, \\
8+, 8-)\end{array}$ & $\begin{array}{l}\text { No } \\
\text { change }\end{array}$ & 0.67 & - \\
\hline $\mathrm{CDH} 23$ & 10:73377314 & $\begin{array}{c}\mathrm{C}>\mathrm{C} / \\
\mathrm{G}, \\
\mathrm{G} / \mathrm{G}\end{array}$ & rs7903772 & $\begin{array}{l}\text { c. } 1134+ \\
164 C>G\end{array}$ & $\begin{array}{l}\text { intron_- } \\
\text { variant }\end{array}$ & $\mathrm{Het}^{2}$ & $\begin{array}{c}\text { C: } 11 \\
(50 \%, 5+, \\
6-) \\
\text { G: } 11 \\
(50 \%, 5+, \\
6-)\end{array}$ & Homo $^{1}$ & N/A & G:43 (100\%, 19+, 24-) \\
\hline $\mathrm{CDH} 23$ & 10:73377330 & $\begin{array}{c}\mathrm{T}>\mathrm{T} / \\
\mathrm{C}\end{array}$ & rs6480536 & $\begin{array}{l}\text { c. } 1134+ \\
180 \mathrm{~T}>\mathrm{C}\end{array}$ & $\begin{array}{l}\text { intron_- } \\
\text { variant }\end{array}$ & $\mathrm{Het}^{2}$ & $\begin{array}{c}\text { C: } 11(55 \%, \\
5+, 6-) \\
\text { T: } 9(45 \%, \\
4+, 5-)\end{array}$ & $\begin{array}{l}\text { No } \\
\text { change }\end{array}$ & N/A & - \\
\hline $\mathrm{CDH} 23$ & $10: 73434888$ & $\begin{array}{l}\mathrm{G}>\mathrm{G} / \\
\mathrm{C}, \mathrm{C} / \mathrm{C}\end{array}$ & rs1227049 & c.1469G $>C$ & $\begin{array}{c}\text { missense } \\
\text { variant }\end{array}$ & Het $^{2}$ & $\begin{array}{c}\text { C:21 (57\%, } \\
9+, 12-) \\
\text { G: } 16(43 \%, \\
8+, 8-)\end{array}$ & Homo $^{1}$ & 0.19 & C:105 (100\%, 51+, 54-) \\
\hline $\mathrm{CDH} 23$ & 10:73455201 & $\begin{array}{c}\mathrm{T}>\mathrm{T} / \\
\mathrm{C}\end{array}$ & rs3752752 & c. $2316 \mathrm{~T}>\mathrm{C}$ & $\begin{array}{c}\text { synony- } \\
\text { mous_- } \\
\text { variant }\end{array}$ & $\mathrm{Het}^{2}$ & $\begin{array}{c}\mathrm{C}: 12(44 \%, \\
6+, 6-) \\
\mathrm{T}: 15(56 \%, \\
7+, 8-)\end{array}$ & $\begin{array}{l}\text { No } \\
\text { change }\end{array}$ & 0.63 & - \\
\hline $\mathrm{CDH} 23$ & 10:73537978 & $\begin{array}{l}\mathrm{C}>\mathrm{C} / \\
\mathrm{T}, \mathrm{T} / \mathrm{T}\end{array}$ & $\begin{array}{l}\text { rs1076 } \\
2480\end{array}$ & c. $5100 \mathrm{C}>\mathrm{T}$ & $\begin{array}{l}\text { synony- } \\
\text { mous_- } \\
\text { variant }\end{array}$ & $\mathrm{Het}^{2}$ & $\begin{array}{c}\mathrm{C}: 14(70 \%, \\
8+, 6-) \\
\mathrm{T}: 6(30 \%, \\
3+, 3-)\end{array}$ & Homo $^{1}$ & 0.18 & T:47 (100\%, 24+, 23-) \\
\hline $\mathrm{CDH} 23$ & $10: 73544086$ & $\begin{array}{c}\mathrm{G}>\mathrm{G} / \\
\mathrm{A}, \mathrm{A} / \\
\mathrm{A}\end{array}$ & $\begin{array}{l}\text { rs } 380 \\
2711\end{array}$ & c. $5411 \mathrm{G}>\mathrm{A}$ & $\begin{array}{c}\text { missense } \\
\text { variant }\end{array}$ & $\mathrm{Het}^{2}$ & $\begin{array}{c}\text { A: } 13(52 \%, \\
7+, 6-) \\
\text { G: } 12(48 \%, \\
5+, 7-)\end{array}$ & Homo $^{1}$ & 0.15 & A:50 (100\%, 27+, 23-) \\
\hline $\mathrm{CDH} 23$ & $10: 73550969$ & $\begin{array}{c}\mathrm{G}>\mathrm{A} / \\
\mathrm{A}\end{array}$ & $\begin{array}{c}\text { rs104 } \\
6026\end{array}$ & c. $6130 \mathrm{G}>\mathrm{A}$ & $\begin{array}{c}\text { missense } \\
\text { variant }\end{array}$ & $\begin{array}{l}\text { No } \\
\text { change }\end{array}$ & - & Homo $^{1}$ & 0.31 & A:85 (100\%, 41+,44-) \\
\hline
\end{tabular}


GRCh37) and Variant Calling Format (VCF) was produced through GATK' Haplotype Caller tool. The VCF file was manually validated using Integrated Genomics Viewer (IGV) and analyzed on Illumina's Variant Studio to check the deafness associated genes.

\section{RESULTS}

The use of inherited disease genes sequencing panel identified the causative and novel variants in deafness related genes (GJB2, MYO7A, CDH23, TH and EVC2) in deaf brothers.

Variants in GJB2 gene: Two variants C>T/T (rs7623, c. ${ }^{*} 1152 \mathrm{G}>\mathrm{A}$ ) and C>A/A (rs9237, c. ${ }^{* 1067 G>T)}$ in GJB2 gene were found common in both brothers. In younger brother two additional variants in GJB2 gene were also identified which were $A>G / G$ (rs7988691, c. $\left.{ }^{*} 1277 \mathrm{~T}>\mathrm{C}\right), \quad \mathrm{A}>\mathrm{G} / \mathrm{G} \quad$ (rs3751385, c. $\left.{ }^{*} 84 \mathrm{~T}>\mathrm{C}\right)$ (Table-I).

Variants in MYO7A gene: Three common missense variation $\mathrm{T}>\mathrm{C} / \mathrm{C}(\mathrm{rs} 1052030, \mathrm{c} .47 \mathrm{~T}>\mathrm{C}), \mathrm{C}>\mathrm{A} / \mathrm{A}$ (rs948962, c.5860C $>\mathrm{A}), \quad \mathrm{A}>\mathrm{T} / \mathrm{T} \quad(\mathrm{rs} 2276288$, c.4996A $>$ T) in MYO7A were found in both brothers (Table-I).

Variants in $\mathrm{CDH} 23$ gene: The missense variant which is common in both brothers in $\mathrm{CDH} 23$ gene is $\mathrm{G}>\mathrm{A} / \mathrm{A}(\mathrm{rs} 1227051$, c.4723G $>\mathrm{A}) . \mathrm{C}>\mathrm{C} / \mathrm{G}$, G/G (rs7903772, c.1134+164C>G), G>G/C, C/C (rs1227049, c.1469G>C), C>C/T, T/T (rs10762480, c.5100C > T), G>G/A, A/A (rs3802711, c.5411G>A) in $\mathrm{CDH} 23$ were also identified in both brothers. Furthermore, G>A/A (rs10466026, c.6130G>A) in $\mathrm{CDH} 23$ were only found in younger brother. Three additional variants $\mathrm{T}>\mathrm{T} / \mathrm{C}$ (rs3802720, c.366T $>\mathrm{C}$ ), $\mathrm{T}>\mathrm{T} / \mathrm{C} \quad(\mathrm{rs} 6480536, \quad \mathrm{c} .1134+180 \mathrm{~T}>\mathrm{C}), \quad \mathrm{T}>\mathrm{T} / \mathrm{C}$ (rs3752752, c.2316T>C) were found only in elder brother (Table-I).

Novel variants: In the same way novel variants in $\mathrm{TH}(\mathrm{G}>\mathrm{G} / \mathrm{A}$, c. $43 \mathrm{C}>\mathrm{T}), \mathrm{EVC} 2(\mathrm{G}>\mathrm{G} / \mathrm{A}$, c. $2614 \mathrm{C}>\mathrm{T}$ ) were found in younger brother.
One novel missense variation MYO7A (G>A/A, c.2476G>A) was also found in MYO7A in both brothers (Table-II).

\section{DISCUSSION}

Most frequently implicated genes in autosomal recessive non-syndromic hearing loss (ARNSHL) are GJB2 followed by SLC26A4 (OMIM: 605646), MYO15A (OMIM: 602666), OTOF (OMIM: 603681), and $C D H 23 .{ }^{15}$ Impact of GJB2 on HL has been determined previously in European (35delG, 167delT) ${ }^{16}$

This study evaluated the association of GJB2, MYO7A, CDH23, TH and EVC2 with deaf in Pakistani brothers. The variations were in $3^{\prime}$-UTR of GJB2, coding region of MYO7A and $C D H 23$ (Table-I). Common homozygous variants in both brothers in 3'-UTR of GJB2 were (rs9237, c. ${ }^{*} 1067 \mathrm{G}>\mathrm{T}$ ) and (rs7623, c. $\left.{ }^{*} 1152 \mathrm{G}>\mathrm{A}\right)$ which had already been reported in Portuguese family. These findings support the same in Portuguese family. ${ }^{17}$ Hence this study strongly suggests that these two homozygous variant in GJB2 are responsible for deafness in these patients.3'-UTR often contain regulatory elements, variation in this region affect the spatial and temporal gene expression. So the variation in $3^{\prime}$-UTR of GJB2 may also affect expression of GJB2 resulting to deafness.

The genetic variation in deafness varies amongst different populations. Deletion of $\mathrm{T}$ at position 167 (mutation 167delT) and $\mathrm{G}$ at position 35 of the GJB2 (mutation 35delG) results in premature chain termination in Nonsyndromic Neurosensory Autosomal Recessive Deafness (NSRD) in Italian patients. ${ }^{9}$ These findings represents that the variation in GJB2 affect the normal function of GJB2 leading to HL or deafness. Syndromic and non-syndromic

Table-II: Novel variation detected in EVC2, TH, and MYO7A genes in both brothers.

\begin{tabular}{|c|c|c|c|c|c|c|c|c|}
\hline Gene & $\begin{array}{c}\text { Vari- } \\
\text { ant }\end{array}$ & $H G V S c$ & Chr & Consequence & SIFT & PolyPhen & Elder brother & $\begin{array}{l}\text { Younger } \\
\text { brother }\end{array}$ \\
\hline EVC2 & $\begin{array}{c}\mathrm{G}>\mathrm{G} / \\
\mathrm{A}\end{array}$ & $\begin{array}{c}\mathrm{c} .2614 \\
\mathrm{C}>\mathrm{T}\end{array}$ & 4 & $\begin{array}{c}\text { missense } \\
\text { variant }\end{array}$ & $\begin{array}{c}\text { Deleterious } \\
\quad(0.04)\end{array}$ & $\begin{array}{c}\text { Probably damaging } \\
(0.997)\end{array}$ & No change & $\mathrm{Het}^{2}$ \\
\hline $\mathrm{TH}$ & $\begin{array}{c}\mathrm{G}>\mathrm{G} / \\
\mathrm{A}\end{array}$ & $\begin{array}{l}\text { c. } 43 \\
\mathrm{C}>\mathrm{T}\end{array}$ & 11 & $\begin{array}{c}\text { missense } \\
\text { variant }\end{array}$ & $\begin{array}{l}\text { Deleterious } \\
\quad(0)\end{array}$ & $\begin{array}{c}\text { Probably damaging } \\
(0.999)\end{array}$ & No change & $\mathrm{Het}^{2}$ \\
\hline $\begin{array}{l}\text { MY- } \\
\text { O7A }\end{array}$ & $\begin{array}{c}\mathrm{G}>\mathrm{A} / \\
\mathrm{A}\end{array}$ & $\begin{array}{c}\mathrm{c} .2476 \\
\mathrm{G}>\mathrm{A}\end{array}$ & 11 & $\begin{array}{c}\text { missense } \\
\text { variant }\end{array}$ & $\begin{array}{l}\text { Deleterious } \\
\text { (0) }\end{array}$ & benign (0.258) & Homo $^{1}$ & Homo $^{1}$ \\
\hline
\end{tabular}

1: Homozygous, 2: Heterozygous 
hearing impairment are caused by mutation within MYO7A in humans. More than 80 MYO7A mutations have been identified and are known to inherit in a recessive manner. ${ }^{11}$ This gene encode protein, the myosin VIIA, expressed in inner ear, retina, testis and lungs. Lack of adequate myosin VIIA function within the cochlear hair cells leads to development of deafness. ${ }^{18}$ In present study we report homozygous novel mutation in coding region of MYO7A (G>A/A, c.2476G>A) in both brothers. Apart from this novel mutation, this study also reports three other missense variants in MYO7A in both brothers. Three of these variants are reported in gentamicin-induced vestibular dysfunction (rs948962), ${ }^{19}$ malignant melanoma (rs2276288 and rs1052030) ${ }^{20}$ and are not reported in deafness. To our knowledge, this is the first study to report these missense variants in deafness.

Common variants, G>A/A, (rs1227051, c. $4723 \mathrm{G}>\mathrm{A}$ ) in $\mathrm{CDH} 23$ were identified in both brothers in homozygous form which had also been reported in Korean HL patients as a nonsynonymous mutation. ${ }^{21}$ The same variation is presumed as polymorphism in Japanese population with NSHL. ${ }^{22}$ Therefore, the present study is an agreement with previous studies. Three additional variants $\mathrm{T}>\mathrm{T} / \mathrm{C} \quad(\mathrm{rs} 3802720$, c.366T $>\mathrm{C}), \mathrm{T}>\mathrm{T} / \mathrm{C}$ (rs6480536, c.1134+180T>C), T>T/C (rs3752752, c. $2316 \mathrm{~T}>\mathrm{C}$ ) in $\mathrm{CDH} 23$ were found only in elder brother. It is suggested that the three additional variations in $\mathrm{CDH} 23$ might be in favor of more deafness in elder brother because his hearing ability was less than the younger brother.

In addition, Dopamine (DA) modulate amino acid neurotransmitter including GABA and has a role in auditory pathways and low-level secretion of GABA leads to deafness. ${ }^{23} \mathrm{TH}$ is the rate limiting enzyme in dopamine synthesis and in return it is regulated by feedback mechanism. ${ }^{24}$ Variation found in $\mathrm{TH}$ (c.43C>T) possibly affect the hearing ability. Apart from that, this study also identified novel deleterious mutation in EVC2 gene (c.2614C>T) only in younger brother which has already been known to be involved in Pakistani family with EVC syndrome and profound deafness. ${ }^{25}$ Therefore, it is concluded that these novel mutation may be of functional consequences on the causative variants and help in increasing the severity of the deafness. We have shown for the first time in Pakistan the novel mutations in deaf patients.
Limitations of the study: Firstly, it reports only two brothers of the family. We could not test the apparently unaffected members of the family and therefore cannot comment upon the zygosity of the genetic mutations. Secondly, the sequence analysis was not validated by Sanger Sequencing. Although there is no consensus amongst the scientific community on the need to validate NGS results with Sanger sequencing. ${ }^{26}$ Lastly, no mechanistic studies were performed to assess the precise role of these novel variants in the pathogenesis of deafness.

\section{CONCLUSION}

This study identified variations in GJB2, MYO7A, $\mathrm{CDH} 23, \mathrm{TH}$ and $E V C 2$ in deaf brothers. The three additional variations in $\mathrm{CDH} 23$ might be in favor of profound deafness in elder brothers as he was deafer comparatively. Therefore, it is concluded that all the identified variants in this study may contribute to disease pathology. This pilot study is a proof of principle for high level study for deafness profiling in Pakistani population, which will be helpful in genetic counseling and to arrange marriages out of family to prevent genetic disease. It is also concluded that the family with recessive diseases should conduct the premarital genetic testing before the consanguineous marriages. The identified variants need to be confirmed by Sanger sequencing or NGS on large sample size.

Grant Support \& Financial Disclosures: Rehman Medical Institute (RMI), Peshawar.

Declaration of interest: The authors confirm that there are no known conflicts of interest associated with this publication. There is no financial interest in the outcome of the study.

\section{REFERENCE}

1. Rao TS, Asha MR, Sambamurthy K, Rao KJ. Consanguinity: Still a challenge. Indian J Psychiatry. 2009;51(1):3-5. doi: 10.4103/0019-5545.44897.

2. National Institute of Population Studies (NIPS) [Pakistan] and ICF International. 2013. Pakistan Demographicand Health Survey 2012-13. Islamabad, Pakistan, and Calverton, Maryland, USA: NIPS and ICF International.

3. Shawky RM, Elsayed SM, Zaki ME, El-Din SM, Kamal FM. Consanguinity and its relevance to clinical genetics. Egypt J Med Hum Genet. 2013;14(2):157-164. doi: 10.1016/j.ejmhg.2013.01.002.

4. Reddy MV, Bindu LH, Reddy PP, Rani PU. Role of consanguinity in congenital neurosensory deafness. Int J Human Genet. 2006;6(4):357-358. doi: 10.1080/09723757.2006.11885980 
5. Gao X, Dai P. Impact of next-generation sequencing on molecular diagnosis of inherited non-syndromic hearing loss. J Otol. 2014;9(3):122-125. doi:10.1016/j. joto.2014.11.003.

6. Zhang F, Xiao Y, Xu L, Zhang X, Zhang G, Li J, et al. Mutation analysis of the common deafness genes in patients with nonsyndromic hearing loss in linyi by SNPscan assay. Biomed Res Int. 2016. doi: 10.1155/2016/1302914.

7. Harris KC, Erbe CB, Firszt JB, Flanary VA, Wackym PA. A novel connexin 26 compound heterozygous mutation results in deafness. Laryngoscope. 2002;112(7):1159-1162. doi: 10.1097/00005537-200207000-00003.

8. Dbouk HA, Mroue RM, El-Sabban ME, Talhouk RS. Connexins: A myriad of functions extending beyond assembly of gap junction channels. Cell Commun Signal. 2009;7(1):4. doi: 10.1186/1478-811X-7-4.

9. Zelante L, Gasparini P, Estivill X, Melchionda S, D'Agruma $\mathrm{L}$, Govea $\mathrm{N}$, et al. Connexin26 mutations associated with the most common form of non-syndromic neurosensory autosomal recessive deafness (DFNB1) in Mediterraneans. Hum Mol Genet. 1997;6(9):1605-1609. doi: 10.1093/ hmg/6.9.1605.

10. Hussain S, Khan MH, Khan MT, Zeb S, Haseeb M, Tariq AU. Association of GJB2 gene mutations with non syndromic autosomal recessive deafness in different populations of the world. Int J Bas App Sci. 2014;3(4):521.

11. Stenson PD, Ball EV, Mort M, Phillips AD, Shiel JA, Thomas NS, et al. Human gene mutation database (HGMD®): 2003 update. Hum Mutat. 2003;21(6):577-581. doi: 10.1002/humu.10212.

12. Todi SV, Sivan-Loukianova E, Jacobs JS, Kiehart DP, Eberl DF. Myosin VIIA, important for human auditory function, is necessary for Drosophila auditory organ development. PLoS One. 2008;3(5):e2115.

13. Becirovic E, Ebermann I, Nagy D, Zrenner E, Seeliger MW, Bolz HJ. Usher syndrome type 1 due to missense mutations on both $\mathrm{CDH} 23$ alleles: investigation of mRNA splicing. Hum Mutat. 2008;29(3):452. doi: 10.1002/ humu.9526

14. Bolz H, von Brederlow B, Ramirez A, Bryda EC, Kutsche $\mathrm{K}$, Nothwang HG, et al. Mutation of $\mathrm{CDH} 23$, encoding a new member of the cadherin gene family, causes Usher syndrome type 1D. Nat Genet. 2001;27(1):108-112. doi: $10.1038 / 83667$

15. Hilgert N, Smith RJ, Van Camp G. Forty-six genes causing nonsyndromic hearing impairment: which ones should be analyzed in DNA diagnostics? Mutat Res. 2009;681(2):189196. doi: 10.1016/j.mrrev.2008.08.002.

16. Gasparini $P$, Rabionet $R$, Barbujani G, Melchionda S, Petersen $M$, Brondum-Nielsen $K$, et al. High carrier frequency of the 35delG deafness mutation in European populations. Eur J Hum Genet. 2000;8(1):19. doi: 10.1038/sj.ejhg.5200406.

17. Matos TD, Simoes-Teixeira H, Caria H, Cascao R, Rosa H, $\mathrm{O}^{\prime}$ Neill $\mathrm{A}$, et al. Assessing noncoding sequence variants of GJB2 for hearing loss association. Genetics Res Int. 2011;2011. doi: 10.4061/2011/827469.
18. Hasson T, Heintzelman MB, Santos-Sacchi J, Corey DP, Mooseker MS. Expression in cochlea and retina of myosin VIIa, the gene product defective in Usher syndrome type 1B. Proc Natl Acad Sci. 1995;92(21):9815-9819. doi: 10.1073/ pnas.92.21.9815.

19. Roth SM, Williams SM, Jiang L, Menon KS, Jeka JJ. Susceptibility genes for gentamicin-induced vestibular dysfunction. J Vestib Res. 2008;18(1):59-68.

20. Fernandez LP, Milne RL, Pita G, Floristan U, Sendagorta E, Feito $M$, et al. Pigmentation-related genes and their implication in malignant melanoma susceptibility. Exp Dermatol. 2009;18(7):634-642. doi: 10.1111/j.16000625.2009.00846.x.

21. Woo HM, Park HJ, Park MH, Kim BY, Shin JW, Yoo WG, et al. Identification of $\mathrm{CDH} 23$ mutations in Korean families with hearing loss by whole-exome sequencing. BMC Med Genet. 2014;15(1):46. doi: 10.1186/1471-2350-15-46.

22. Wagatsuma M, Kitoh R, Suzuki H, Fukuoka H, Takumi Y, Usami S. Distribution and frequencies of $\mathrm{CDH} 23$ mutations in Japanese patients with non-syndromic hearing loss. Clin Genet. 2007;72(4):339-344. doi: 10.1111/j.13990004.2007.00833.x.

23. Fyk-Kolodziej BE, Shimano T, Gafoor D, Mirza N, Griffith RD, Gong TW, et al. Dopamine in the auditory brainstem and midbrain: co-localization with amino acid neurotransmitters and gene expression following cochlear trauma. Front Neuroanat. 2015;9:88. doi: 10.3389/fnana.2015.00088.

24. Gordon SL, Quinsey NS, Dunkley PR, Dickson PW. Tyrosine hydroxylase activity is regulated by two distinct dopamine-binding sites. J Neurochem. 2008;106(4):16141623. doi: 10.1111/j.1471-4159.2008.05509.x.

25. Umair M, Seidel H, Ahmed I, Ullah A, Haack TB, Alhaddad $B$, et al. Ellis-van Creveld syndrome and profound deafness resulted by sequence variants in the EVC/EVC2 and TMC1 genes. J Genet. 2017;96(6):1005-1014.

26. Baudhuin LM, Lagerstedt SA, Klee EW, Fadra N, Oglesbee D, Ferber MJ. Confirming variants in next-generation sequencing panel testing by Sanger sequencing. J Mol Diagn. 2015;17(4):456-61. doi: 10.1016/j.jmoldx.2015.03.004.

\section{Author`s Contribution:}

BS conducted the experiment and manuscript writing.

JA secured funding, designed the study and edited the manuscript.

SAH did data analysis of the study.

YMY did review and final approval of manuscript. 